\title{
DRY MATTER AND NUTRIENT ACCUMULATION CURVE IN CABBAGE CROP ${ }^{1}$
}

\author{
LUIZ OTÁVIO DUARTE ${ }^{2 *}$, JUNIA MARIA CLEMENTE ${ }^{3}$, ILÍDIO AUGUSTO BORGES CAIXETA ${ }^{4}$, MARCELO DE \\ PAULA SENOSKI ${ }^{4}$, LEONARDO ANGELO DE AQUINO ${ }^{4}$
}

\begin{abstract}
Cabbage cultivars currently cultivated present high yield potential and may present differences regarding absorption and use of nutrients. Thus, studies quantifying plant growth and nutrient accumulation are the basis to improve fertilization efficiency and optimize yield. This study aimed to determine the dry matter and nutrient ( $\mathrm{N}, \mathrm{P}, \mathrm{K}, \mathrm{Ca}, \mathrm{Mg}, \mathrm{S}, \mathrm{Cu}, \mathrm{Fe}, \mathrm{Mn}$, and $\mathrm{Zn}$ ) accumulation curve of cabbage cultivars during two growing seasons. Cultivars Astrus Plus and Green Valley were cultivated during summer-autumn crop season, while Astrus Plus and Fênix during the autumn-winter crop season. Plants were sampled after transplanting at 10-day intervals until harvest. Dry matter and nutrient accumulations are variable with growing season and cultivar. The highest dry matter and nutrient accumulation rates occur in the last ten days of the cycle. Fertilizations with N, P, K, Fe, and Zn should receive more attention due to higher harvest indices.
\end{abstract}

Keywords: Brassica oleracea var. capitata. Nutrient extraction. Harvest index.

\section{CURVA DE ACÚMULO DE MATÉRIA SECA E DE NUTRIENTES PELA CULTURA DO REPOLHO}

RESUMO - As cultivares de repolho utilizadas atualmente têm alto potencial produtivo e podem apresentar diferenças na absorção e utilização de nutrientes. Dessa forma, pesquisas com a quantificação do crescimento das plantas e da acumulação de nutrientes são básicas para melhorar a eficiência de fertilização do solo e otimizar a produção. Objetivou-se, com este trabalho, determinar as curvas de acúmulo de matéria seca (MS) e de nutrientes (N, P, K, Ca, Mg, S, Cu, Fe, Mn e Zn) por cultivares de repolho em duas épocas de cultivo. No verão-outono foram utilizadas as cultivares ‘Astrus Plus' e ‘Green Valley', e no outono-inverno, 'Astrus Plus' e 'Fênix'. As plantas foram amostradas, após o transplante, em intervalos de 10 dias até a colheita. O acúmulo de matéria seca e de nutrientes é variável com a época de cultivo e com a cultivar. As maiores taxas de acúmulo de matéria seca e de nutrientes ocorrem nos 10 últimos dias do ciclo. As adubações com N, P, K, Fe e Zn devem receber maior atenção em razão de apresentarem os maiores índices de colheita.

Palavras-chave: Brassica oleracea var. capitata. Extração de nutrientes. Índice de colheita.

\footnotetext{
${ }^{*}$ Corresponding author

${ }^{1}$ Received for publication in $08 / 01 / 2018$; accepted in $06 / 04 / 2019$.

Paper extracted from the master dissertation of the first author.

${ }^{2}$ Department of Crop Production, Universidade Estadual Paulista "Júlio de Mesquita Filho", Jaboticabal, SP, Brazil; luizotavioduarte@folha.com.br - ORCID: 0000-0003-0187-7456.

${ }^{3}$ Department of Agricultural Sciences, Instituto Federal do Sudeste de Minas Gerais, Manhuaçu, MG, Brazil; junia.clemente@gmail.com ORCID: 0000-0002-2198-9861.

${ }^{4}$ Institute of Agrarian Sciences, Universidade Federal de Viçosa, Rio Paranaíba, MG, Brazil; caixeta.ilidio@gmail.com - ORCID: 00000002-2611-495X, msenoski18@gmail.com - ORCID: 0000-0003-1740-1807, aquino.ufv@gmail.com - ORCID: 0000-0002-7764-730X.
} 


\section{INTRODUCTION}

Recommendations for soil fertility correction and fertilization of cabbage crop are scarce (CECÍLIO FILHO; SILVA; CORTEZ, 2013). Therefore, recommended fertilizer doses usually underestimate the nutrient demand related to high yield and commercial standards of modern cabbage cultivars (AQUINO et al., 2005).

There is a disagreement between fertilizer applications recommended in the literature and those effectively applied by farmers, who usually apply higher nutrient doses. Thus, the current fertilization management does not provide nutrients in balance with crop requirements, which results in waste of fertilizers and low recovery efficiency (ZHANG et al., 2010). Furthermore, brassicas show differences in accumulation as a function of growing seasons and genotypic variability (KOPSELL et al., 2005).

Because of the short cycle of most vegetable crops, nutrient demand is concentrated in the short term. It makes important the knowledge of nutrient absorption and accumulation characteristics at different development stages (CASTOLDI et al., 2009). For this, nutrient accumulation curves should be determined in order to know the time when nutrients are most required, plan more rational cultivation methods, and optimize the recommended dose and time of fertilizer application (BENDER; HAEGELE; BELOW, 2015).

Absorption curves include the nutrient ratio in commercial organs (heads, in the case of cabbage) regarding the total accumulation. This ratio, also known as harvest index, is important for nutrient flow in the soil. The nutrients most accumulated in the commercial organ can lead to soil impoverishment, especially when fertilizations are lower when compared to the exported quantities and nutrient is required in large quantities (AQUINO et al., 2015). Therefore, studies on quantification of plant growth and nutrient accumulation are the basis to improve soil fertility efficiency, optimize yield, and reduce the environmental impact caused by excess fertilizers (CORTEZ et al., 2013).

However, nutrient absorption curve indicates plant need and not the dose to be applied, which varies according to the nutrient recovery efficiency by the crop, which in turn varies as a function of soil type, weather conditions, crop management, and source (CASTOLDI et al., 2009).

Cabbage cultivars currently cultivated have high yield potential and may differ regarding nutrient absorption and use, which leads to the need for determining the nutrient requirement of different cultivars in the growing regions. Thus, this study aimed to determine dry matter $(\mathrm{DM})$ and nutrient $(\mathrm{N}$, $\mathrm{P}, \mathrm{K}, \mathrm{Ca}, \mathrm{Mg}, \mathrm{S}, \mathrm{Cu}, \mathrm{Fe}, \mathrm{Mn}$, and $\mathrm{Zn}$ ) accumulation curve of cabbage cultivars.

\section{MATERIAL AND METHODS}

Nutrient accumulation curves were determined in two growing seasons, the first during summer-autumn and the second during autumnwinter in two commercial fields of cabbage cultivation in São Gotardo, MG. The areas were at an altitude of $1,100 \mathrm{~m}$ and a prevailing Cwa climate according to Köppen-Geiger classification (PEEL; FINLAYSON; McMAHON, 2007). Weather data recorded during the experiment are shown in Figure 1. Soils of both areas are classified as Haplustox (Red Yellow Latosol with a very clayey texture, according to the Brazilian Soil Classification System), whose chemical attributes are shown in Table 1 .

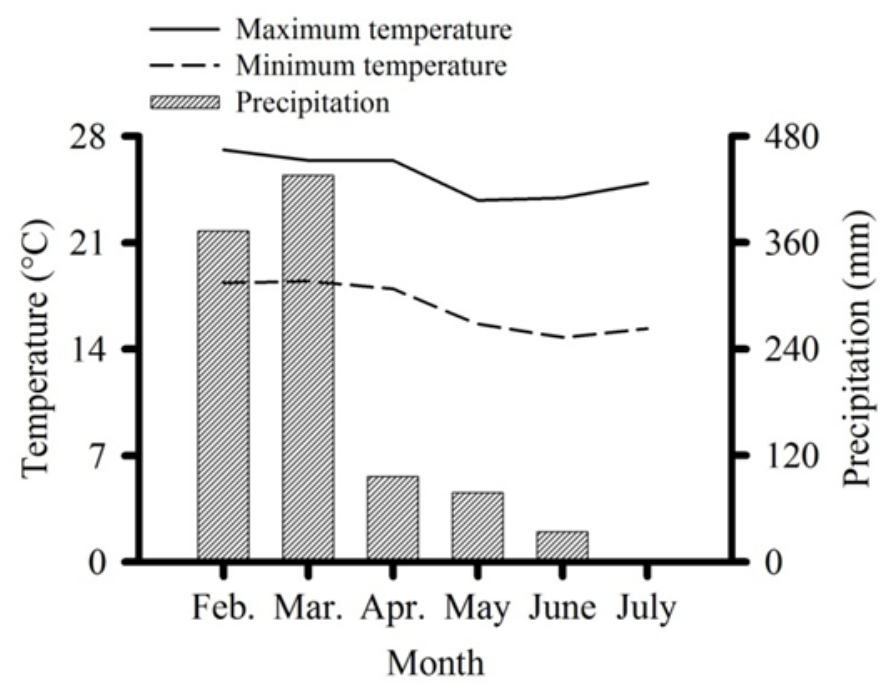

Figure 1. Maximum and minimum temperatures and precipitation during the experimental period. Alto Paranaíba region, MG (2015). 
Table 1. Soil chemical analyses of the experimental areas at a depth at $0-20 \mathrm{~cm}$.

\begin{tabular}{|c|c|c|c|c|}
\hline \multirow{2}{*}{ Chemical attribute } & \multirow{2}{*}{ Unit } & \multirow{2}{*}{ Extractor/Method } & \multicolumn{2}{|c|}{ Growing season } \\
\hline & & & Summer-autumn & Autumn-winter \\
\hline $\mathrm{pH}$ & - & $\mathrm{CaCl}_{2}$ & 5.6 & 5.9 \\
\hline P-rem & $\mathrm{mg} \mathrm{L}^{-1}$ & $\mathrm{CaCl}_{2}$ & 13.4 & 7.4 \\
\hline $\mathrm{P}$ & $\mathrm{mg} \mathrm{dm}{ }^{-3}$ & Mehlich-1 & 33.3 & 24.3 \\
\hline K & $\mathrm{mg} \mathrm{dm} \mathrm{m}^{-3}$ & Mehlich-1 & 86.0 & 97.8 \\
\hline $\mathrm{Ca}$ & $\mathrm{cmol}_{\mathrm{c}} \mathrm{dm}^{-3}$ & $\mathrm{KCl}$ & 3.9 & 4.9 \\
\hline $\mathrm{Mg}$ & $\mathrm{cmol}_{\mathrm{c}} \mathrm{dm}^{-3}$ & $\mathrm{KCl}$ & 1.0 & 1.5 \\
\hline S & $\mathrm{mg} \mathrm{dm}{ }^{-3}$ & Calcium phosphate & 10.0 & 17.0 \\
\hline $\mathrm{B}$ & $\mathrm{mg} \mathrm{dm}{ }^{-3}$ & Hot water & 1.5 & 1.1 \\
\hline $\mathrm{Cu}$ & $\mathrm{mg} \mathrm{dm} \mathrm{m}^{-3}$ & DTPA & 2.6 & 2.3 \\
\hline $\mathrm{Fe}$ & $\mathrm{mg} \mathrm{dm}{ }^{-3}$ & DTPA & 26.0 & 52 \\
\hline $\mathrm{Mn}$ & $m g \mathrm{dm}^{-3}$ & DTPA & 1.5 & 3.2 \\
\hline $\mathrm{Zn}$ & $\mathrm{mg} \mathrm{dm}{ }^{-3}$ & DTPA & 7.5 & 6.7 \\
\hline $\mathrm{Al}$ & $\mathrm{cmol}_{\mathrm{c}} \mathrm{dm}^{-3}$ & $\mathrm{KCl}$ & 0.0 & 0.0 \\
\hline $\mathrm{H}+\mathrm{Al}$ & $\mathrm{cmol}_{\mathrm{c}} \mathrm{dm}^{-3}$ & SMP buffer solution & 3.1 & 2.6 \\
\hline Organic matter & $\mathrm{g} \mathrm{dm}^{-3}$ & - & 38.0 & 29.0 \\
\hline Sum of bases & $\mathrm{cmol}_{\mathrm{c}} \mathrm{dm}^{-3}$ & - & 5.1 & 6.7 \\
\hline Cation exchange capacity & $\mathrm{cmol}_{\mathrm{c}} \mathrm{dm}^{-3}$ & - & 8.3 & 9.3 \\
\hline Base saturation & $\%$ & - & 62.0 & 71.7 \\
\hline
\end{tabular}

$\mathrm{P}$ and $\mathrm{K}-\mathrm{Mehlich}-1$; $\mathrm{Ca}, \mathrm{Mg}$, and $\mathrm{Al}-1 \mathrm{~mol} \mathrm{~L}{ }^{-1} \mathrm{KCl}$; $\mathrm{S}-\mathrm{SO}_{4}-0.01 \mathrm{~mol} \mathrm{~L}^{-1}$ monobasic calcium phosphate; $\mathrm{B}$ - hot water; $\mathrm{Cu}, \mathrm{Fe}, \mathrm{Mn}$, and $\mathrm{Zn}-\mathrm{DTPA}$ at $\mathrm{pH} 7.3 ; \mathrm{H}+\mathrm{Al}-\mathrm{SMP}$ buffer solution at $\mathrm{pH}$ 7.5; Organic matter Walkley-Black.

Soil tillage consisted of a subsoiling, harrowing, and rotary hoeing, with pits spaced at $0.35 \times 0.38 \mathrm{~m}$, resulting in a population of 75.188 plants $\mathrm{ha}^{-1}$. In the summer-autumn, nitrogen, phosphorus, and potassium fertilization consisted of $150 \mathrm{~kg} \mathrm{ha}^{-1}$ of $\mathrm{N}, 850 \mathrm{~kg} \mathrm{ha}^{-1}$ of $\mathrm{P}_{2} \mathrm{O}_{5}$, and $160 \mathrm{~kg}$ $\mathrm{ha}^{-1}$ of $\mathrm{K}_{2} \mathrm{O}$, respectively. In the autumn-winter, 210 $\mathrm{kg} \mathrm{ha}^{-1}$ of $\mathrm{N}, 700 \mathrm{~kg} \mathrm{ha}^{-1}$ of $\mathrm{P}_{2} \mathrm{O}_{5}$, and $320 \mathrm{~kg} \mathrm{ha}^{-1}$ of $\mathrm{K}_{2} \mathrm{O}$ were applied. All fertilizers were broadcast applied and incorporated at planting, including phosphate fertilizers, as adopted by farmers in the Alto Paranaiba region, MG.

In the summer-autumn, seedlings of the cultivars Astrus Plus and Green Valley were transplanted to the field on February 13, 2015, and harvested on April 23, 2015. The cultivar Astrus Plus has good compactness, good market acceptance, and medium to large sized heads, with slightly flattened shape and weight ranging from 1.4 to $2.2 \mathrm{~kg}$. It is the cultivar most used by farmers in the Alto Paranaíba region, $\mathrm{MG}$, as it can be cultivated throughout the year. The cultivar Green Valley presents vigorous foliage and medium-sized heads, with flattened globular shape and weight ranging from 2.0 to 2.5 $\mathrm{kg}$.

In the autumn-winter, seedlings of the cultivars Astrus Plus and Fênix were transplanted to the cultivation area on May 1, 2015, and harvested on July 10 and 20, 2015, respectively. The cultivar Fênix presents medium semi-flattened heads and mean weight from 2.5 to $3.0 \mathrm{~kg}$, with the preferential growing season in the winter.

All cultivars had seedlings produced in 200cell trays under a protected environment and using an agricultural substrate based on coconut fiber and vermiculite, with transplanting at 35 days after sowing.

Weed management was carried out with a pre -planting application of oxyfluorfen (2-chloro- $\alpha, \alpha, \alpha$ trifluoro-p-tolyl 3-ethoxy-4-nitrophenyl ether) and manual wedding over the cycle when necessary. Phytosanitary management of the experiments followed the procedure adopted in the commercial area, in which decision-making was based on pest and disease monitoring. The crop was irrigated by a central pivot when necessary, with a water depth calculated from the data collected in weather stations installed near the experiments.

Plants were sampled after transplanting at 10day intervals until harvest. Twelve plants (four replications with three plants each) were sampled at each collection time by cutting them close to the soil surface. Cabbage crop was harvested when plants presented well-formed heads and compactness 
required for commercialization, which occurred at 70 days after transplanting (DAT) in the summerautumn season and 70 and 80 DAT for the cultivars Fênix and Astrus Plus, respectively, in the autumnwinter season. Plants were divided into commercial (head) and non-commercial parts (outer leaves + stem) at that time.

After each sampling, samples were washed to remove impurities and dried in a forced air circulation oven at $70{ }^{\circ} \mathrm{C}$ for $72 \mathrm{~h}$. Subsequently, these samples were ground in a Wiley mill fitted with a $1.27-\mathrm{mm}$ sieve to determine nutrient contents (N, P, K, Ca, Mg, S, Cu, Fe, Mn, and $\mathrm{Zn}$ ), according to Malavolta, Vitti, and Oliveira (1997).

The data were analyzed by descriptive statistics. Curves and equations of DM and nutrient accumulation were adjusted using the software Sigma Plot v. 10.0. Harvest indices were given by the percentage of DM and nutrients accumulated in the heads in relation to their total amount accumulated in the whole plant.

\section{RESULTS AND DISCUSSION}

\section{Accumulation curve, export, and harvest index of DM and macronutrients}

Two distinct phases were observed for DM accumulation (Figure 2). The first phase (up to 30 DAT) comprised the initial period of crop development, in which the growth rates were lower for the cultivars Astrus Plus and Green Valley in the summer-autumn, with values of 27.9 and $31.4 \mathrm{~kg} \mathrm{ha}^{-1} \mathrm{day}^{-1}$, respectively, when compared to the cultivars Astrus Plus and Fênix in the autumnwinter, with values of 41.2 and $42.0 \mathrm{~kg} \mathrm{ha}^{-1}$ day $^{-1}$, respectively. It can be attributed to the stress caused by the transplanting or slow initial growth that is characteristic of crucifers. This result was also verified by Übelhör, Gruber, and Claupein (2014) in white cabbage and Castoldi et al. (2009) and Gondim et al. (2011), who observed around 17 and $20 \%$ of the total accumulation, respectively, up to 30 DAT in cauliflower.

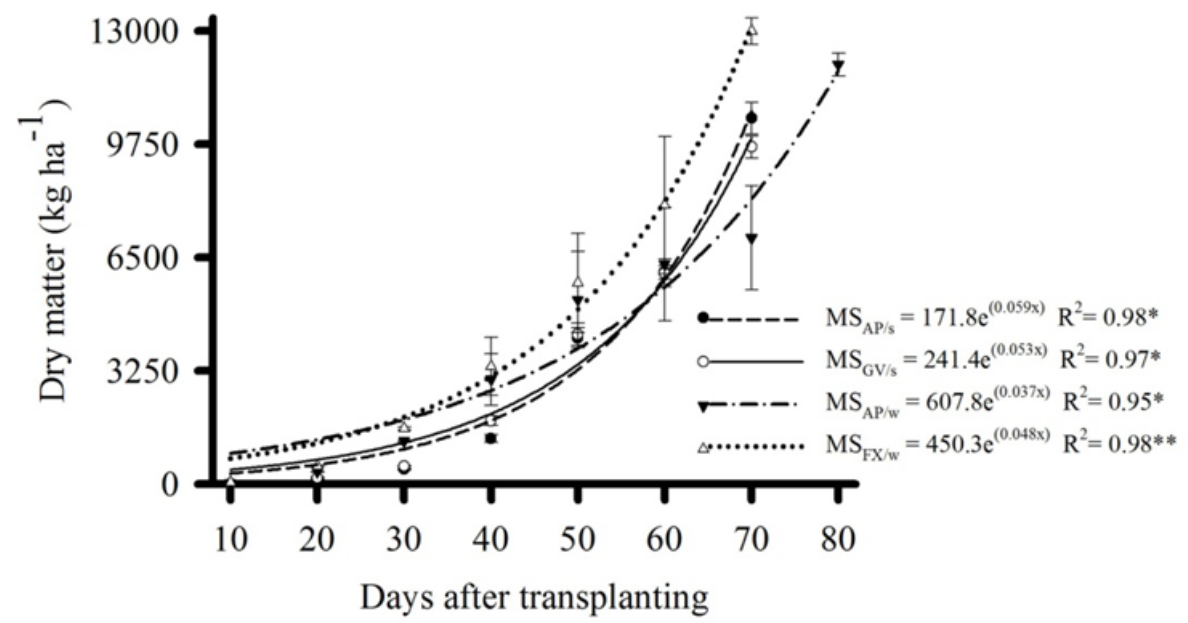

Figure 2. Dry matter accumulation curve for the cultivars Astrus Plus (AP/s) and Green Valley (GV/s) in the summerautumn and Astrus Plus (AP/w) and Fênix $(\mathrm{FX} / \mathrm{w})$ in the autumn-winter.

$* *$ and *are significant at 1 and $5 \%$, respectively, by the t-test.

The second phase started at approximately 30 DAT (Figure 2). There was a higher shoot growth, which was more pronounced in the last ten days of the cycle for all cultivars. The highest DM accumulation rates were observed during this period, with values of $476.1 \mathrm{~kg} \mathrm{ha}^{-1}$ day $^{-1}$ in the summerautumn and $362.7 \mathrm{~kg} \mathrm{ha}^{-1} \mathrm{day}^{-1}$ in the autumn-winter for the cultivar Astrus Plus, and 387.7 and $494.2 \mathrm{~kg}$ $\mathrm{ha}^{-1}$ day $^{-1}$ for the cultivars Green Valley and Fênix, respectively.

Comparatively, from 60 to 70 DAT, for the cultivar Astrus Plus in the autumn-winter, and 50 to 60 DAT, for the other cultivars, the accumulation rates were $263.9,238.8,250.6$, and $305.8 \mathrm{~kg} \mathrm{ha}^{-1}$ day $^{-1}$ for the cultivars Astrus Plus in the summerautumn, Green Valley and Astrus Plus in autumnwinter, and Fênix. The highest DM accumulation rate during this period may be related to an intense cell division during the final stage of head formation.

Shoot DM production was higher at harvest, with values of 9,673 to $10,499 \mathrm{~kg} \mathrm{ha}^{-1}$ in the summer -autumn and 12,043 to $12,995 \mathrm{~kg} \mathrm{ha}^{-1}$ in the autumnwinter (Table 2). These values are higher when compared to those found by Aquino et al. (2009) $\left(8,308 \mathrm{~kg} \mathrm{ha}^{-1}\right)$ and Correa, Cardoso, and Claudio (2013) $\left(6,156\right.$ and $\left.3,563 \mathrm{~kg} \mathrm{ha}^{-1}\right)$, which may be attributed to the use of different hybrids. However, Cecílio Filho et al. (2011) found $6,438 \mathrm{~kg} \mathrm{ha}^{-1}$ for the cultivar Astrus Plus, which may be related to the lower plant population used. Moreover, the higher DM production of the present study may also be attributed to higher yields, with values of 124.5 , 152.3, 106.7, and 142.8 $\mathrm{tha}^{-1}$ for the cultivar Astrus Plus in summer-autumn and autumn-winter, Green Valley and Fênix, respectively. 
Table 2. Amount of dry matter and macronutrients accumulated ${ }^{\dagger}$ in cabbage heads and outer leaves and harvest index for the cultivars Astrus Plus and Green Valley in the summer-autumn growing season and Astrus Plus and Fênix in the autumnwinter growing season.

\begin{tabular}{|c|c|c|c|c|c|c|}
\hline \multirow{2}{*}{ Variable } & \multicolumn{2}{|c|}{ Accumulation $\left(\mathrm{kg} \mathrm{ha}^{-1}\right)$} & \multirow{2}{*}{$\begin{array}{c}\text { Harvest } \\
\text { index }(\%)\end{array}$} & \multicolumn{2}{|c|}{ Accumulation $\left(\mathrm{kg} \mathrm{ha}^{-1}\right)$} & \multirow{2}{*}{$\begin{array}{c}\text { Harvest } \\
\text { index }(\%)\end{array}$} \\
\hline & Heads & Outer leaves & & Heads & Outer leaves & \\
\hline & \multicolumn{6}{|c|}{ Summer-autumn } \\
\hline & & Astrus Plus- & & & Green Valley- & \\
\hline Dry matter & $7,620 \pm 490.8$ & $2,879 \pm 230.9$ & $72 \pm 2.1$ & $6,528 \pm 273.2$ & $3,145 \pm 145.3$ & $68 \pm 1.3$ \\
\hline $\mathrm{N}$ & $254 \pm 8.3$ & $79 \pm 5.9$ & $76 \pm 1.7$ & $188 \pm 7.2$ & $84 \pm 4.6$ & $69 \pm 1.5$ \\
\hline $\mathrm{P}$ & $65 \pm 5.9$ & $14 \pm 1.7$ & $82 \pm 1.1$ & $42 \pm 4.5$ & $15 \pm 1.0$ & $74 \pm 1.1$ \\
\hline K & $419 \pm 50.7$ & $210 \pm 25.9$ & $67 \pm 3.9$ & $356 \pm 27.6$ & $170 \pm 5.8$ & $68 \pm 1.9$ \\
\hline $\mathrm{Ca}$ & $72 \pm 6.4$ & $234 \pm 65.2$ & $24 \pm 4.4$ & $350 \pm 15.8$ & $290 \pm 3.0$ & $55 \pm 1.1$ \\
\hline $\mathrm{Mg}$ & $21 \pm 1.8$ & $20 \pm 7.4$ & $52 \pm 7.8$ & $60 \pm 2.1$ & $34 \pm 0.6$ & $63 \pm 0.9$ \\
\hline \multirow[t]{3}{*}{$\mathrm{S}$} & $47 \pm 2.5$ & $45 \pm 1.4$ & $51 \pm 1.4$ & $38 \pm 1.6$ & $44 \pm 5.2$ & $46 \pm 3.5$ \\
\hline & \multirow{2}{*}{\multicolumn{6}{|c|}{ Autumn-winter }} \\
\hline & & Astrus Plus- & & & -Fênix- & \\
\hline Dry matter & $9,024 \pm 148.7$ & $3,020 \pm 270.9$ & $73 \pm 1.5$ & $9,031 \pm 216.8$ & $3,964 \pm 280.6$ & $68 \pm 1.4$ \\
\hline $\mathrm{N}$ & $223 \pm 4.7$ & $70 \pm 1.5$ & $76 \pm 0.7$ & $241 \pm 4.0$ & $104 \pm 2.5$ & $70 \pm 0.8$ \\
\hline $\mathrm{P}$ & $49 \pm 1.4$ & $12 \pm 0.6$ & $80 \pm 0.7$ & $51 \pm 2.3$ & $16 \pm 0.9$ & $76 \pm 1.2$ \\
\hline $\mathrm{K}$ & $335 \pm 13.4$ & $131 \pm 1.4$ & $72 \pm 1.0$ & $367 \pm 27.2$ & $161 \pm 15.4$ & $70 \pm 2.9$ \\
\hline $\mathrm{Ca}$ & $48 \pm 3.2$ & $115 \pm 8.8$ & $30 \pm 1.4$ & $49 \pm 3.2$ & $157 \pm 17.9$ & $24 \pm 1.7$ \\
\hline $\mathrm{Mg}$ & $17 \pm 0.6$ & $15 \pm 0.7$ & $54 \pm 1.1$ & $23 \pm 0.3$ & $28 \pm 1.3$ & $45 \pm 1.1$ \\
\hline $\mathrm{S}$ & $39 \pm 0.9$ & $29 \pm 2.1$ & $57 \pm 2.2$ & $46 \pm 2.3$ & $39 \pm 3.6$ & $54 \pm 3.1$ \\
\hline
\end{tabular}

${ }^{\dagger}$ Mean \pm standard deviation.

Yields were higher in the autumn-winter growing season than those found in the summerautumn, which may be related to the occurrence of milder temperatures (Figure 1), which allow a higher brassica growth. According to Rahman, Hadley, and Pearson (2007), the optimal temperature range for cauliflower after curd initiation is 19 to $23{ }^{\circ} \mathrm{C}$. Kalisz et al. (2012) verified a higher yield in Chinese cabbage (B. rapa var. chinensis) under mean temperatures from 16.7 to $20.0^{\circ} \mathrm{C}$.

A little difference was observed between cultivars and growing seasons for the harvest index of DM (Table 2). The harvest indices ranged from 67 to $73 \%$ in the summer-autumn and 69 to $75 \%$ in the autumn-winter. These values are higher when compared to those found by Cecílio Filho et al. (2011) for the cultivar Astrus Plus (57\%) and Correa, Cardoso, and Claudio (2013) for the cultivar Kenzan ( 47 and $49 \%$ ), which may be due to the higher yield obtained in the present study and the highest plant population.

Regarding macronutrient accumulation, $\mathrm{N}$ accumulation curves were similar to that of DM accumulation only in the summer-autumn (Figure 3a). The highest accumulation rate at this growing season was observed from 60 to 70 DAT, with a value of $14.2 \mathrm{~kg} \mathrm{~N} \mathrm{ha}^{-1}$ day $^{-1}$ for the cultivar Astrus Plus and $10.5 \mathrm{~kg} \mathrm{~N} \mathrm{ha}^{-1}$ day $^{-1}$ for Green Valley. The accumulation rates were constant in the autumnwinter, with values of 4.3 and $5.8 \mathrm{~kg} \mathrm{~N}^{-1}$ day $^{-1}$ for the cultivar Astrus Plus and Fênix, respectively.

Phosphorus accumulation curves were also similar to that of DM accumulation (Figure $3 b$ ). The highest $\mathrm{P}$ accumulation rates were observed in the last ten days of the cycle for all cultivars and growing seasons. The values found in the summerautumn were 3.8 and $2.7 \mathrm{~kg} \mathrm{P} \mathrm{ha}{ }^{-1}$ day $^{-1}$ for the cultivars Astrus Plus and Green Valley, respectively, and 1.8 and $2.4 \mathrm{~kg} \mathrm{P} \mathrm{ha}{ }^{-1}$ day $^{-1}$ for Astrus Plus and Fênix, respectively, in the autumn-winter.

Potassium accumulation rate was continuous over the cycle for all cultivars and growing seasons (Figure 3c). The observed K contents were 10.7 and $8.8 \mathrm{~kg} \mathrm{ha}^{-1}$ day $^{-1}$ for the cultivars Astrus Plus and Green Valley in the summer-autumn growing season, respectively, and 6.8 and $5.8 \mathrm{~kg} \mathrm{ha}^{-1}$ day $^{-1}$ for Astrus Plus and Green Valley in the autumnwinter, respectively.

Calcium accumulation curves were different according to the growing seasons (Figure 3d). They were similar to the DM accumulation curve in the summer-autumn, but presented a decrease in the accumulation rate after 40 and 50 DAT for the cultivars Astrus Plus and Fênix, respectively, in in the autumn-winter. The highest accumulation rates were found between 60 and 70 DAT in the summerautumn, with a value of $13.5 \mathrm{~kg} \mathrm{Ca} \mathrm{ha}{ }^{-1} \mathrm{day}^{-1}$ for Astrus Plus and $17.7 \mathrm{~kg} \mathrm{Ca} \mathrm{ha}{ }^{-1}$ day $^{-1}$ for Green Valley. However, the highest accumulation rates in the autumn-winter were observed from 30 to 40 DAT for the cultivar Astrus Plus (5.6 kg Ca ha ${ }^{-1} \mathrm{day}^{-1}$ ) and 40 to 50 DAT for the cultivar Fênix (5.9 $\mathrm{kg} \mathrm{Ca} \mathrm{ha}^{-1}$ day $\left.^{-1}\right)$. 
- Astrus Plus/summer-auntumn Green Valley/summer-auntumn

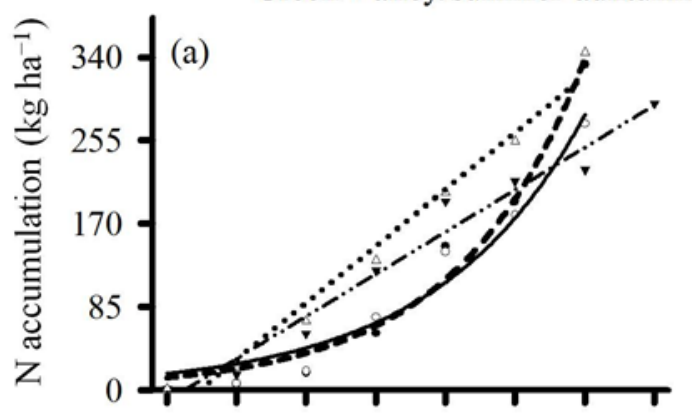

$\mathrm{N}_{\mathrm{AP} / \mathrm{s}}=7.323 \mathrm{e}^{(0.0547 \mathrm{x})}$

$\mathrm{N}_{\mathrm{GV} / \mathrm{s}}=10.61 \mathrm{e}^{(0.0468 \mathrm{x})}$

$\mathrm{N}_{\mathrm{AP} / \mathrm{w}}=-53.98+4.313 \mathrm{x}$

$\mathrm{N}_{\mathrm{FX} / \mathrm{w}}=-85.02+5.801 \mathrm{x}$

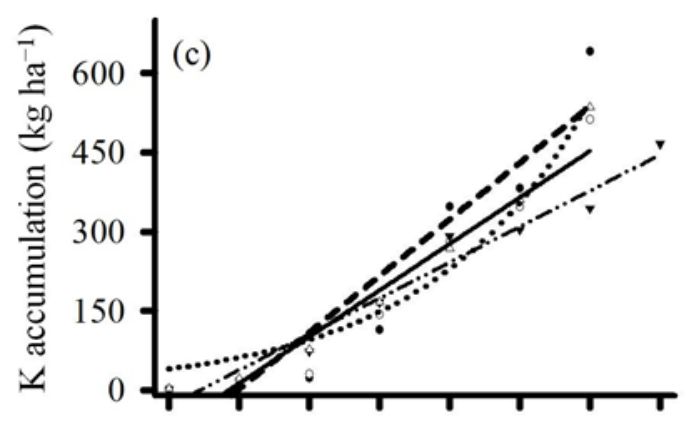

$\mathrm{K}_{\mathrm{AP} / \mathrm{s}}=-212.7+10.71 \mathrm{x}$

$\mathrm{K}_{\mathrm{GV} / \mathrm{s}}=-163.3+8.802 \mathrm{x}$

$\mathrm{K}_{\mathrm{AP} / \mathrm{w}}=-97.68+6.789 \mathrm{x}$

$\mathrm{K}_{\mathrm{FX} / \mathrm{w}}=25.72 \mathrm{e}^{(0.0437 \mathrm{x})}$

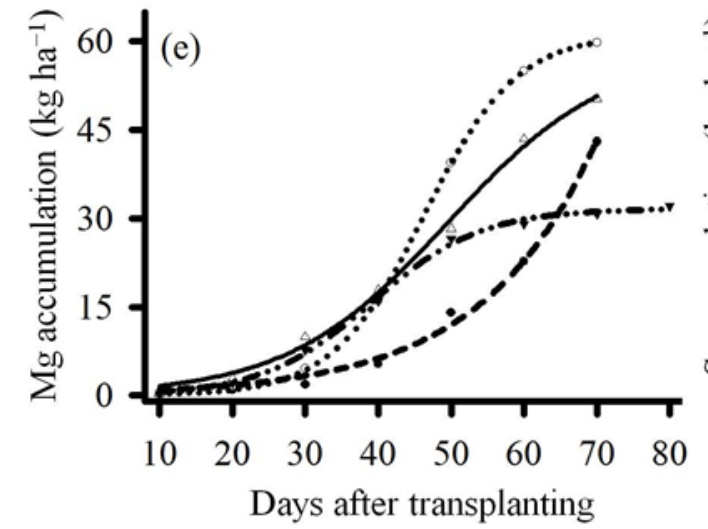

$\mathrm{Mg}_{\mathrm{AP} / \mathrm{s}}=0.4774 \mathrm{e}^{(0.0644 \mathrm{x})}$
$\left.\mathrm{Mg}_{\mathrm{GV} / \mathrm{s}}=61.23 /\left\{1+\mathrm{e}^{[-(\mathrm{x}-46.33) / 6.303]}\right)\right\}$
$\mathrm{Mg}_{\mathrm{AP} / \mathrm{w}}=31.64 /\left\{1+\mathrm{e}^{[-(\mathrm{x}-39.18) 7.460]}\right\}$
$\mathrm{Mg}_{\mathrm{FX/ \textrm {w }}}=58.71 /\left\{1+\mathrm{e}^{[-(\mathrm{x}-49.63) / 11.08]}\right\}$

$\mathrm{R}^{2}=0.99^{* *} \quad \mathrm{~S}_{\mathrm{AP} / \mathrm{s}}=\mathrm{e}^{(0.0652 \mathrm{x})}$

$\mathrm{R}^{2}=0.99 * * * \mathrm{~S}_{\mathrm{GV} / \mathrm{s}}=\mathrm{e}^{(0.0639)}$

$\mathrm{R}^{2}=0.99^{* * * *} \mathrm{~S}_{\mathrm{AP} / \mathrm{w}}=78.88 /\left\{1+\mathrm{e}^{[-(\mathrm{x}-52.24) / 11.49]}\right\}$

$\mathrm{R}^{2}=0.99 * * * \mathrm{~S}_{\mathrm{FX} / \mathrm{w}}=116.3 /\left\{1+\mathrm{e}^{[-(\mathrm{x}-58.15) / 12.83]}\right\}$ v Astrus Plus/auntumn-winter

Fênix/auntumn-winter

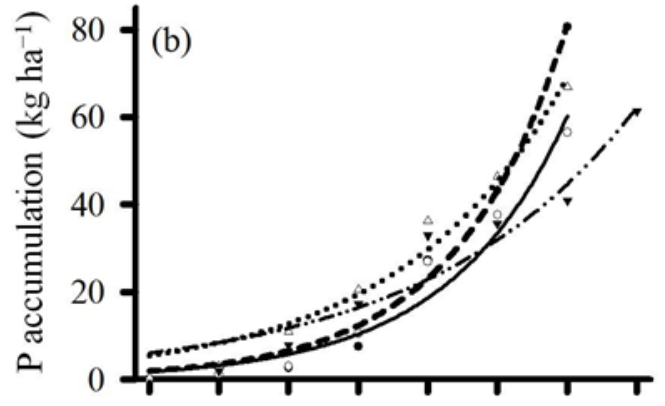

$\mathrm{R}^{2}=0.98 * * *$

$\mathrm{R}^{2}=0.95 * * *$

$\mathrm{R}^{2}=0.93 *$

$\mathrm{R}^{2}=0.97 *$

Figure 3. Nitrogen (a), phosphorus (b), potassium (c), calcium (d), magnesium (e), and sulfur (f) accumulation curves for the cultivars Astrus Plus (AP/s) and Green Valley (GV/s) in the summer-autumn and Astrus Plus (AP/w) and Fênix (FX/w) in the autumn-winter.

$* * *, * *$, and *are significant at $0.1,1$, and $5 \%$, respectively, by the t-test. 
The Mg accumulation curve presented a similar behavior to that of DM for the cultivar Astrus Plus in the summer-autumn season, while the accumulation rate decreased from 40 DAT in the autumn-winter, which was also observed for the cultivars Green Valley and Fênix after 50 DAT (Figure 3e). Therefore, the period with the highest $\mathrm{Mg}$ accumulation rate was different between cultivars and growing seasons. Astrus Plus presented the highest accumulation rate, with values of $2.1 \mathrm{~kg}$ $\mathrm{Mg} \mathrm{ha}^{-1}$ day $^{-1}$ from 60 to 70 DAT in the summerautumn and $1.0 \mathrm{~kg} \mathrm{Mg} \mathrm{ha}{ }^{-1}$ day $^{-1}$ from 30 to 40 DAT in the autumn-winter. The highest accumulation rates were found from 40 to 50 DAT for the cultivars Green Valley and Fênix, with values of 2.3 and $1.3 \mathrm{~kg} \mathrm{ha}^{-1} \mathrm{day}^{-1}$, respectively.

Sulfur accumulation curves were similar to the respective DM accumulation curves in the summer-autumn (Figure 3f). Thus, the highest accumulation rate was observed in the last ten days of the cycle for the cultivars Astrus Plus and Green Valley, with values of 4.6 and $4.1 \mathrm{~kg} \mathrm{~S} \mathrm{ha}^{-1} \mathrm{day}^{-1}$, respectively. In the autumn-winter, sulfur accumulation increased up to 60 DAT for both cultivars, with the highest rates observed from 50 to 60 DAT, with values of $1.7 \mathrm{~kg} \mathrm{~S} \mathrm{ha}^{-1}$ day $^{-1}$ for Astrus Plus and $2.2 \mathrm{~kg} \mathrm{~S}^{-1}$ day $^{-1}$ for Fênix.

In general, a higher nutrient accumulation was observed close to cabbage harvest time, unlike cauliflower, in which all macronutrients are accumulated in the middle third of the crop cycle (CASTOLDI et al., 2009; TAKEISHI; CECÍLIO FILHO; OLIVEIRA, 2009). Takeishi, Cecílio Filho, and Oliveira (2009) attributed the increased nutrient accumulation in cauliflower in the middle third of its cycle to the increased number of leaves, leaf area, and DM during this period. This pattern is different in cabbage (Figure 2) most likely because its absorption curve was determined before inflorescence emission and during a period of full vegetative growth.

The amount of macronutrients accumulated in the heads (export) of the cultivar Astrus Plus was higher in the summer-autumn when compared to the autumn-winter for all nutrients (Table 2). This result agrees with Citak and Sonmez (2010), who found higher $\mathrm{P}, \mathrm{K}$, and $\mathrm{Mg}$ contents in cabbage heads cultivated under higher temperature.

The most exported macronutrient for all cultivars was $\mathrm{K}$ (Table 2). The exported $\mathrm{K}$ content for the cultivar Astrus Plus was higher in the summer -autumn when compared to the autumn-winter growing season, with values of 419 and $335 \mathrm{~kg} \mathrm{~K}$ $\mathrm{ha}^{-1}$, respectively. These contents were similar for the other cultivars, i.e., $343 \mathrm{~kg} \mathrm{~K} \mathrm{ha}^{-1}$ for Green Valley and $367 \mathrm{~kg} \mathrm{ha}^{-1}$ for Fênix. These values exceed those found by Aquino et al. (2009) and Correa, Cardoso, and Claudio (2013), who observed values of 295 and $197 \mathrm{~kg} \mathrm{~K} \mathrm{ha}^{-1}$, respectively. The highest extractions obtained in this study can be attributed to a higher DM production because the applied doses and soil $\mathrm{K}$ contents were similar to those of the cited studies. A significant and positive effect was observed for plant population on K export (AQUINO et al., 2009), which may explain the high quantity of exported $\mathrm{K}$ since the population was higher when compared to those used in other studies.

Potassium was the most accumulated nutrient by cabbage, which was also observed by Correa, Cardoso, and Claudio (2013), who found that only planting fertilization with $240 \mathrm{~kg} \mathrm{~K} \mathrm{~K}_{2} \mathrm{O} \mathrm{ha}^{-1}$ was enough to reach the maximum yield, without significant differences from the $\mathrm{K}$ topdressing fertilization. However, as observed in this study, $\mathrm{K}$ is continuously demanded by the crop throughout the cycle (Figure $3 \mathrm{c}$ ). Because $\mathrm{K}$ has a susceptibility to leaching in sandy soils and under high-intensity precipitation, applying its full dose at planting cannot be a good agricultural practice. Moreover, considering the extraction values (Table 2) and yield obtained in the present study, the dose of $240 \mathrm{~kg}$ $\mathrm{K}_{2} \mathrm{O}$ ha $^{-1}$ is not enough to supply the demand of the cultivars. Higher doses to be applied suggest the need for splitting the fertilization for a better recovery efficiency.

Nitrogen was the second most exported macronutrient by all cultivars. The cultivar Astrus Plus also presented a higher export in the summerautumn when compared to autumn-winter, with values of 254 and $223 \mathrm{~kg} \mathrm{~N} \mathrm{ha}^{-1}$, respectively (Table 2). Also, export reached values of $188 \mathrm{~kg} \mathrm{~N} \mathrm{ha}^{-1}$ for the cultivar Green Valley and $241 \mathrm{~kg} \mathrm{~N} \mathrm{ha}^{-1}$ for the cultivar Fênix (Table 2). These $\mathrm{N}$ contents were below that found by Aquino et al. (2009) (279 kg $\mathrm{ha}^{-1}$ ), which could be explained by the higher $\mathrm{N}$ content, as they found a linear response between $\mathrm{N}$ content and the applied $\mathrm{N}$, which was estimated by applying $300 \mathrm{~kg} \mathrm{~N} \mathrm{ha}{ }^{-1}$. These results corroborate Sturm et al. (2010), who observed an accumulation of $246 \mathrm{~kg} \mathrm{~N} \mathrm{ha}^{-1}$ by applying $200 \mathrm{~kg} \mathrm{~N} \mathrm{ha}^{-1}$ in white cabbage, and Yun and Ro (2009), who verified a linear response of $\mathrm{N}$ accumulation with $\mathrm{N}$ doses.

A difference was observed between growing seasons for the third most exported nutrient, which was $\mathrm{Ca}$ in the summer-autumn and $\mathrm{P}$ in the autumnwinter (Table 2). The cultivar Astrus Plus exported $72 \mathrm{~kg} \mathrm{Ca} \mathrm{ha}^{-1}$, and the Green Valley exported $182 \mathrm{~kg}$ $\mathrm{Ca} \mathrm{ha}^{-1}$ in the summer-autumn. Similar export values were observed among cultivars in the autumn-winter, with values of 48 and $49 \mathrm{~kg} \mathrm{Ca} \mathrm{ha}^{-1}$ for Astrus Plus and Fênix, respectively. Therefore, the amount of $\mathrm{Ca}$ exported by the cultivar Green Valley was higher when compared to that observed in the other cultivars, which is different from the range of values found in the literature. Aquino et al. (2009) observed an export of $88 \mathrm{~kg} \mathrm{Ca} \mathrm{ha}^{-1}$, while Correa, Cardoso, and Claudio (2013) reported extraction of $35 \mathrm{~kg} \mathrm{Ca}$ $\mathrm{ha}^{-1}$, both studies using the hybrid Kenzan and similar soil Ca contents.

Although yield was lower in the summer- 
autumn in comparison with the autumn-winter, the cultivar Astrus Plus showed higher $\mathrm{P}$ export (Table 2). It may be related to the higher $\mathrm{P}$ content in the soil and the highest dose used in the summerautumn growing season $\left(33.3 \mathrm{mg} \mathrm{dm}^{-3}\right.$ and $850 \mathrm{~kg}$ $\mathrm{P}_{2} \mathrm{O}_{5} \mathrm{ha}^{-1}$, respectively), which allowed a higher accumulation by plants. Cabbage can mobilize and absorb $\mathrm{P}$ from the soil by additional mechanisms, such as exudation of the organic acid citrate, which increases $\mathrm{P}$ recovery efficiency (DECHASSA; SCHENK, 2004). $P$ export was similar in the cultivars Green Valley and Fênix, with values of 42 and $51 \mathrm{~kg} \mathrm{P} \mathrm{ha}^{-1}$, respectively. In soil with high $\mathrm{P}$ availability $\left(\mathrm{P}_{\text {resin }}=93.0 \mathrm{mg} \mathrm{dm}{ }^{-3}\right)$, Cecílio Filho, Silva, and Cortez (2013) found $16 \mathrm{~kg} \mathrm{P} \mathrm{ha}^{-1}$ as the maximum export by applying $360 \mathrm{~kg} \mathrm{P}_{2} \mathrm{O}_{5} \mathrm{ha}^{-1}$, which is lower than the values found in the present study. This observation may be related to the hybrid Fuyutoyo used and yield obtained by the authors $\left(69.6 \mathrm{t} \mathrm{ha}^{-1}\right)$. This difference caused by hybrids and yield can also explain the export higher than $28 \mathrm{~kg} \mathrm{P} \mathrm{ha}{ }^{-1}$, as observed by Aquino et al. (2009).

The amount of $\mathrm{S}$ exported by the cultivar Astrus Plus in the summer-autumn was similar to that of Fênix, with 47 and $46 \mathrm{~kg} \mathrm{ha}^{-1}$, respectively (Table 2). The similarity was also observed between the export values of the cultivars Green Valley and Astrus Plus in the autumn-winter, with 38 and $39 \mathrm{~kg} \mathrm{ha}^{-1}$, respectively. However, all cultivars presented export lower than the $50 \mathrm{~kg} \mathrm{~S}^{-1}$ found by Aquino et al. (2009), which may be related to the lower S availability in the soils of the present study.

Magnesium was the last macronutrient in order of export and the cultivar Astrus Plus exported less when compared to the other cultivars, regardless of the growing season (Table 2). This cultivar exported $21 \mathrm{~kg} \mathrm{ha}^{-1}$ in the summer-autumn and $17 \mathrm{~kg} \mathrm{ha}^{-1}$ in autumn-winter. The cultivar Green Valley exported $26 \mathrm{~kg} \mathrm{ha}^{-1}$ and Fênix exported $23 \mathrm{~kg} \mathrm{ha}^{-1}$. These exports were higher when compared to those observed by Correa, Cardoso, and Claudio (2013), which is probably due to the higher DM production of the present study.

The nutrients $\mathrm{N}, \mathrm{P}$, and $\mathrm{K}$ presented the highest harvest indices and, in general, the cultivar Astrus Plus had higher harvest indices than other cultivars (Table 2). The harvest indices varied from 74 to $82 \%$ for $\mathrm{P}, 69$ to $76 \%$ for $\mathrm{N}$, and 65 to $72 \%$ for $\mathrm{K}$. Thus, greater attention should be given to the replacement of these nutrients in order to avoid soil impoverishment (BENDER; HAEGELE; BELOW, 2015), as they are absorbed in high amounts and have a larger partition for leaves that comprise the head, resulting in the high export rate.
Accumulation curve, export, and harvest index of micronutrients

All cultivars, except Fênix, presented practically constant $\mathrm{Cu}$ accumulation rates up to the last ten days of the cycle when a considerable increase in this rate was observed (Figure 4a). Thus, the accumulation rates during this period were 4.0, 9.7, and $4.3 \mathrm{~g} \mathrm{Cu} \mathrm{ha}^{-1} \mathrm{day}^{-1}$ for the cultivars Astrus Plus in summer-autumn and autumn-winter and Green Valley, respectively. The highest accumulation rate for the cultivar Fênix occurred from 40 to 50 DAT, with a value of $29.8 \mathrm{~g} \mathrm{Cu} \mathrm{ha}^{-1}$ day ${ }^{-1}$, which is considered high and probably due to the contamination by foliar sprayings with cupric fungicides.

Iron accumulation rate decreased at 50 DAT for the cultivars Green Valley and Astrus Plus in the autumn-winter and 60 DAT for the cultivar Fênix (Figure $4 \mathrm{~b}$ ). Thus, the highest accumulation rate was verified from 40 to 50 DAT, with values of 109.7 and $21.5 \mathrm{~g} \mathrm{Fe} \mathrm{ha}^{-1} \mathrm{day}^{-1}$ for Green Valley and Astrus Plus in the autumn-winter, respectively. Also, the highest accumulation rate occurred from 50 to 60 DAT for the cultivar Fênix, with a value of $45.6 \mathrm{~g} \mathrm{Fe}$ $\mathrm{ha}^{-1}$. The cultivar Astrus Plus showed a distinct behavior in the summer-autumn in relation to the other cultivars, with increasing $\mathrm{Fe}$ accumulation over the cycle, especially in the last ten days of the cycle, in which the accumulation rate was $125.9 \mathrm{~g} \mathrm{Fe} \mathrm{ha}^{-1}$ day $^{-1}$.

Manganese accumulation curves practically followed DM accumulation curves, with the highest accumulation rates observed in the last ten days of the cycle for all cultivars (Figure 4c). Thus, 14.5 and $16.4 \mathrm{~g} \mathrm{Mn} \mathrm{ha}^{-1}$ day $^{-1}$ were found in the summerautumn for the cultivars Astrus Plus and Green Valley, respectively, and 7.9 and $39.8 \mathrm{~g} \mathrm{Mn}$ $\mathrm{ha}^{-1}$ day $^{-1}$ in the autumn-winter for Astrus Plus and Fênix, respectively.

Finally, the highest $\mathrm{Zn}$ accumulation rates also occurred in the last ten days of the cycle for all cultivars (Figure 4d). The accumulation rates obtained in the autumn-winter were 39.4 and $8.4 \mathrm{~g}$ $\mathrm{Zn} \mathrm{ha}^{-1}$ day $^{-1}$ for the cultivars Astrus Plus and Green Valley, respectively. On the other hand, the rates in the autumn-winter were 8.0 and $11.5 \mathrm{~g} \mathrm{Zn} \mathrm{ha}^{-1}$ day $^{-1}$ for Astrus Plus and Fênix, respectively.

As observed for macronutrients, the highest micronutrient accumulation rate in cabbage occurred in the last 10 days of the cycle, which is different from cauliflower, in which the highest accumulation occurred in the middle third of the crop cycle (CASTOLDI et al., 2009; TAKEISHI; CECÍLIO FILHO; OLIVEIRA, 2009). 

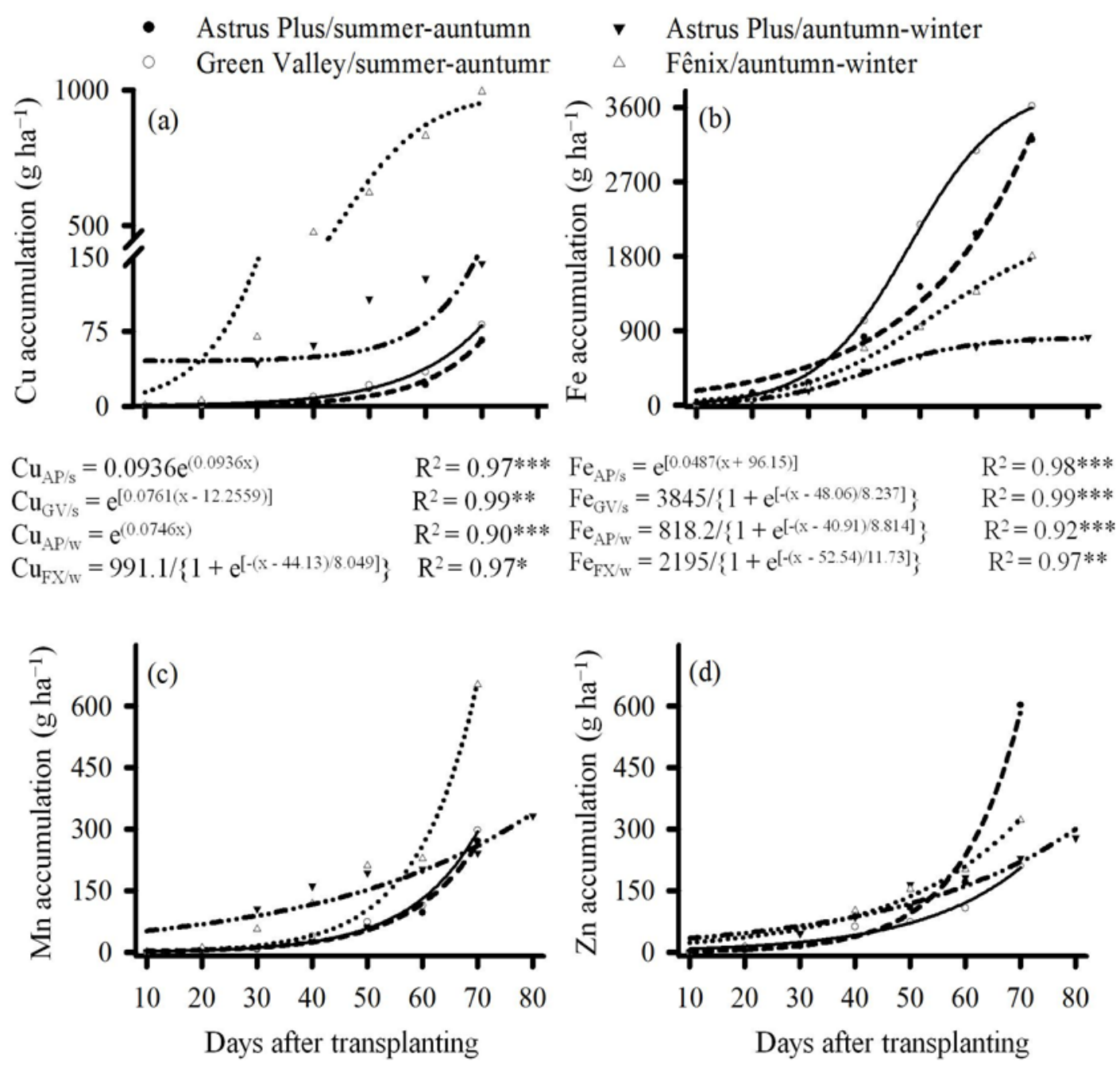

$$
\begin{array}{llll}
\mathrm{Mn}_{\mathrm{AP} / \mathrm{s}}=\mathrm{e}^{(0.0797 \mathrm{x})} & \mathrm{R}^{2}=0.98^{* * *} \quad \mathrm{Zn}_{\mathrm{AP} / \mathrm{s}}=\mathrm{e}^{(0.0910 \mathrm{x})} & \mathrm{R}^{2}=0.97^{* * *} \\
\mathrm{Mn}_{\mathrm{GV} / \mathrm{s}}=\mathrm{e}^{(0.0812 \mathrm{x})} & \mathrm{R}^{2}=0.98^{* * *} & \mathrm{Zn}_{\mathrm{GV} / \mathrm{s}}=5.058 \mathrm{e}^{(0.0529 \mathrm{x})} & \mathrm{R}^{2}=0.97 * \\
\mathrm{Mn}_{\mathrm{AP} / \mathrm{w}}=40.00 \mathrm{e}^{(0.0267 \mathrm{x})} & \mathrm{R}^{2}=0.88^{*} & \mathrm{Zn}_{\mathrm{AP} / \mathrm{w}}=25.10 \mathrm{e}^{(0.0310 \mathrm{x})} & \mathrm{R}^{2}=0.92^{*} \\
\mathrm{Mn}_{\mathrm{FX} / \mathrm{w}}=\mathrm{e}^{(0.0927 \mathrm{x})} & \mathrm{R}^{2}=0.93^{* * *} \quad \mathrm{Zn}_{\mathrm{FX/W}}=15.38 \mathrm{e}^{(0.0436 \mathrm{x})} & \mathrm{R}^{2}=0.97^{*}
\end{array}
$$

Figure 4. Copper (a), iron (b), manganese (c), and zinc (d) accumulation curves for the cultivars Astrus Plus (AP/s) and Green Valley (GV/s) in the summer-autumn and Astrus Plus (AP/w) and Fênix (FX/w) in the autumn-winter. $* * *, * *$, and * are significant at $0.1,1$, and $5 \%$, respectively, by the t-test.

Regarding the order of micronutrient export, Fe was the most exported nutrient, with higher values in the summer-autumn in relation to autumnwinter (Table 3), which can be explained by the higher precipitation during this first growing season (Figure 1). It occurred because the higher precipitation maintained the soil under field capacity, which led to a possible $\mathrm{O}_{2}$ deficiency. Thus, there is a reduction in soil redox potential and hence iron, which increases the concentration of this nutrient in the plant tissues due to its increased solubility when in the reduced form (PEZESHKI, 2001). The export ranged from 1,674 to $2,106 \mathrm{~g} \mathrm{Fe}$ $\mathrm{ha}^{-1}$ in the summer-autumn and 448 to $956 \mathrm{~g} \mathrm{Fe} \mathrm{ha}^{-1}$ in the autumn-winter, which are higher than the
$355 \mathrm{~g} \mathrm{Fe} \mathrm{ha}^{-1}$ observed by Correa, Cardoso, and Claudio (2013).

Zinc was the second micronutrient in the export order, except for the cultivar Green Valley (Table 3). However, the cultivar Astrus Plus in the summer-autumn showed the highest $\mathrm{Zn}$ export. Zinc export reached 506 and $205 \mathrm{~g} \mathrm{Zn} \mathrm{ha}^{-1}$ in the summer -autumn for the cultivars Astrus Plus and Green Valley, respectively. On the other hand, Zn export was similar between cultivars in the autumn-winter, with values of $206 \mathrm{~g} \mathrm{Zn} \mathrm{ha}^{-1}$ for the cultivar Astrus Plus and $213 \mathrm{~g} \mathrm{Zn} \mathrm{ha}^{-1}$ for Fênix. However, all these values are above $122 \mathrm{~g} \mathrm{Zn} \mathrm{ha}^{-1}$ observed by Correa, Cardoso, and Claudio (2013). 
Table 3. Amount of micronutrients accumulated ${ }^{\dagger}$ in cabbage heads and outer leaves and harvest index for the cultivars Astrus Plus and Green Valley in the summer-autumn and Astrus Plus and Fênix cultivars in the autumn-winter.

\begin{tabular}{|c|c|c|c|c|c|c|}
\hline \multirow{2}{*}{ Nutrient } & \multicolumn{2}{|c|}{ Accumulation $\left(\mathrm{g} \mathrm{ha}^{-1}\right)$} & \multirow{2}{*}{$\begin{array}{c}\text { Harvest } \\
\text { index }(\%)\end{array}$} & \multicolumn{2}{|c|}{ Accumulation $\left(\mathrm{g} \mathrm{ha}^{-1}\right)$} & \multirow{2}{*}{$\begin{array}{c}\text { Harvest } \\
\text { index (\%) }\end{array}$} \\
\hline & Heads & Outer leaves & & Heads & Outer leaves & \\
\hline & \multicolumn{6}{|c|}{ Summer-autumn } \\
\hline & & Astrus Plus- & & & İreen Valley- & \\
\hline $\mathrm{Cu}$ & $29 \pm 2.7$ & $40 \pm 5.5$ & $42 \pm 4.6$ & $26 \pm 1.7$ & $56 \pm 11.8$ & $32 \pm 3.5$ \\
\hline $\mathrm{Fe}$ & $2,106 \pm 145.2$ & $1,104 \pm 41.5$ & $66 \pm 2.1$ & $1,674 \pm 86.0$ & $1,940 \pm 238.7$ & $47 \pm 2.9$ \\
\hline $\mathrm{Mn}$ & $154 \pm 11.1$ & $118 \pm 5.2$ & $57 \pm 1.3$ & $109 \pm 16.2$ & $183 \pm 34.6$ & $37 \pm 1.3$ \\
\hline \multirow[t]{2}{*}{$\mathrm{Zn}$} & $506 \pm 89.2$ & $97 \pm 15.6$ & $84 \pm 3.3$ & $113 \pm 15.2$ & $98 \pm 10.1$ & $54 \pm 2.0$ \\
\hline & \multicolumn{6}{|c|}{ Autumn-winter } \\
\hline & & Astrus Plus- & & & -Fênix- & \\
\hline $\mathrm{Cu}$ & $67 \pm 3.2$ & $326 \pm 34.1$ & $17 \pm 1.9$ & $64 \pm 4.4$ & $930 \pm 66.9$ & $7 \pm 0.1$ \\
\hline $\mathrm{Fe}$ & $448 \pm 25.8$ & $373 \pm 34.1$ & $55 \pm 3.4$ & $956 \pm 261.6$ & $849 \pm 132.6$ & $52 \pm 6.1$ \\
\hline $\mathrm{Mn}$ & $162 \pm 5.1$ & $171 \pm 1.4$ & $49 \pm 0.9$ & $195 \pm 10.8$ & $457 \pm 21.6$ & $30 \pm 1.4$ \\
\hline $\mathrm{Zn}$ & $203 \pm 7.9$ & $72 \pm 2.5$ & $74 \pm 1.2$ & $213 \pm 11.0$ & $104 \pm 10.9$ & $67 \pm 3.4$ \\
\hline
\end{tabular}

${ }^{\dagger}$ Mean \pm standard deviation.

Manganese was the third micronutrient in the export order and showed a small variation in the amount exported for the cultivar Astrus Plus as a function of growing seasons, with values of 154 and $162 \mathrm{~g} \mathrm{Mn} \mathrm{ha}^{-1}$ in the summer-autumn and autumnwinter, respectively (Table 3 ). The cultivar Fênix was superior to all cultivars in relation to the export, with $195 \mathrm{~g} \mathrm{Mn} \mathrm{ha}^{-1}$, while Green Valley was inferior, with $115 \mathrm{~g} \mathrm{Mn} \mathrm{ha}^{-1}$. Correa, Cardoso, and Claudio (2013) found an extraction of $127 \mathrm{~g} \mathrm{Mn}$ $\mathrm{ha}^{-1}$, which was due to the lower DM production in comparison to the present study.

Copper was the last micronutrient in the export order, with the highest values observed in the autumn-winter (Table 3). It may be related to the higher precipitation during summer-autumn (Figure 1), which maintained the soil continuously under field capacity. Thus, there was possible a reduction in the redox potential, which provided a reduction in $\mathrm{SO}_{4}{ }^{2-}$ to $\mathrm{HS}^{-}$and precipitation of $\mathrm{Cd}$ and $\mathrm{Cu}$ in the form of sulfide minerals, which have a low solubility (PAN et al., 2016). Thus, the export in the autumnwinter was 64 and $67 \mathrm{~g} \mathrm{Cu} \mathrm{ha}^{-1}$ for the cultivars Astrus Plus and Fênix, respectively. However, the cultivars Astrus Plus and Green Valley had values of 29 and $26 \mathrm{~g} \mathrm{Cu} \mathrm{ha}^{-1}$ in the summer-autumn, respectively, which are higher than the $16 \mathrm{~g} \mathrm{Cu} \mathrm{ha}^{-1}$ observed by Correa, Cardoso, and Claudio (2013).

As observed for macronutrients, the cultivar Astrus Plus showed the highest harvest indices for all micronutrients (Table 3). The values ranged from 54 to $84 \%$ for $\mathrm{Zn}, 46$ to $66 \%$ for $\mathrm{Fe}, 30$ to $57 \%$ for $\mathrm{Mn}$, and 6 to $44 \%$ for $\mathrm{Cu}$ between cultivars and growing seasons. Thus, greater attention should be given to soil $\mathrm{Fe}$ and $\mathrm{Zn}$ contents since they present a larger partition for leaves that comprise cabbage head.

\section{CONCLUSIONS}

Dry matter and nutrient accumulation are variable according to growing season and cultivar.
The highest DM and nutrient accumulation rates occur during the last ten days of the cycle.

Fertilizations with $\mathrm{N}, \mathrm{P}, \mathrm{K}, \mathrm{Fe}$, and $\mathrm{Zn}$ should receive more attention due to higher harvest indices.

\section{ACKNOWLEDGMENTS}

To the Conselho Nacional de Desenvolvimento Científico e Tecnológico ( $\mathrm{CNPq})$ for funding the project and providing a research productivity grant to the fifth author. To the Coordenação de Aperfeiçoamento de Pessoal de Nível Superior (CAPES) for granting the scholarship of the first author. To the agricultural group HF Fênix of São Gotardo, MG, for the support during the experiments.

\section{REFERENCES}

AQUINO, L. A. et al. Avanços da pesquisa para o manejo eficiente de nutrientes em hortaliças. In: VISOTTO, L. E. et al. (Eds.). Avanços tecnológicos aplicados à pesquisa na produção vegetal. Rio Paranaíba: UFV-CRP, 2015, v. 1, p. 295-320.

AQUINO, L. A. et al. Efeito de espaçamentos e doses de nitrogênio sobre as características qualitativas da produção do repolho. Horticultura Brasileira, v. 23, n. 1, p. 100-104, 2005.

AQUINO, L. A. et al. Produção de biomassa, teor e exportação de macronutrientes em plantas de repolho em função de doses de nitrogênio e de espaçamentos. Ciência e Agrotecnologia, v. 33, n. 5, p. 1295-1300, 2009.

BENDER, R. R.; HAEGELE, J. W.; BELOW, F. E. Nutrient uptake, partitioning, and remobilization in modern soybean varieties. Agronomy Journal, v. 107, n. 2, p. 563-573, 2015. 
CASTOLDI, R. et al. Crescimento, acúmulo de nutrientes e produtividade da cultura da couve-flor. Horticultura Brasileira, v. 27, n. 4, p. 438-446, 2009.

CECÍLIO FILHO, A. B. et al. Cabbage growth and production in relation to plant density and nitrogen. Agrociencia, v. 45, n. 5, p. 573-582, 2011.

CECÍlio FILHO, A. B.; SILVA, G. S.; CORTEZ, J. W. M. Phosphorus fertilization of 'Fuyutoyo' cabbages in phosphorus-rich Eutrustox soil. Chilean Journal of Agricultural Research, v. 73, n. 3, p. 288-292, 2013.

CITAK, S.; SONMEZ, S. Influence of organic and conventional growing conditions on the nutrient contents of white head cabbage (Brassica oleracea var. capitata) during two successive seasons. Journal of Agricultural and Food Chemistry, v. 58 , n. 3, p. $1788-1793,2010$.

CORREA, C. V.; CARDOSO, A. I. I.; CLAUDIO, M. D. T. R. Yield of cabbage depending on rates and sources of potassium in top dressing. Semina: Ciências Agrárias, v. 34, n. 5, p. 2129-2138, 2013.

CORTEZ, J. W. M. et al. Growth of potato plants of the 'Asterix' Cultivar and accumulation of nutrients. Journal of Agricultural Science, v. 5, n. 7, p. 217226, 2013.

DECHASSA, N.; SCHENK, M. K. Exudation of organic anions by roots of cabbage, carrot, and potato as influenced by environmental factors and plant age. Journal of Plant Nutrition and Soil Science, v. 167, n. 5, p. 623-629, 2004

GONDIM, A. R. O. et al. Curva de crescimento e acúmulo de matéria seca em couve-flor cultivada em substrato. Bioscience Journal, v. 27, n. 1, p. 88-94, 2011.

KALISZ, A. et al. Yield and nutritional quality of several non-heading Chinese cabbage (Brassica rapa var. chinensis) cultivars with different growing period and its modelling. Korean Journal of Horticultural Science and Technology, v. 30, n. 6, p. $650-656,2012$.

KOPSELL, D. E. et al. Variability in elemental accumulations among leafy Brassica oleracea cultivars and selections. Journal of Plant Nutrition, v. 27, n. 10, p. 1813-1826, 2005.

MALAVOLTA, E.; VITTI, G. C.; OLIVEIRA, S. A. Avaliação do estado nutricional das plantas: princípios e aplicações. 2 ed. Piracicaba, SP: Potafos, 1997. $319 \mathrm{p}$
RAHMAN, H. U.; HADLEY, P.; PEARSON, S. Relationship between temperature and cauliflower (Brassica oleracea L. var. botrytis) growth and development after curd initiation. Plant Growth Regulation, v. 52, n. 1, p. 61-72, 2007.

PAN, Y. et al. Solubility of trace metals in two contaminated paddy soils exposed to alternating flooding and drainage. Geoderma, v. 261, s/n., p. 59 $-69,2016$

PEEL, M. C.; FINLAYSON, B. L.; McMAHON. T. A. Updated world map of the Köppen-Geiger climate classification. Hydrology and Earth System Sciences, v. 4, n. 2, p. 1633-1644, 2007.

PEZESHKI, S. R. Wetland plant responses to soil flooding. Environmental and Experimental Botany, v. 46, n. 3, p. 299-312, 2001.

ŠTURM, M. et al. Effect of different fertilisation and irrigation practices on yield, nitrogen uptake and fertiliser use efficiency of white cabbage (Brassica oleracea var. capitata L.). Scientia Horticulturae, v. 125 , n. 2, p. 103-109, 2010.

TAKEISHI, J.; CECÍLIO FILHO, A. B.; OLIVEIRA, P. R. Crescimento e acúmulo de nutrientes em couve-flor 'Verona'. Bioscience Journal, v. 25, n. 4, p. 1-10, 2009

ÜBELHÖR, A.; GRUBER, S.; CLAUPEIN, W. Influence of tillage intensity and nitrogen placement on nitrogen uptake and yield in strip-tilled white cabbage (Brassica oleracea convar. capitata var. alba). Soil and Tillage Research, v. 144, n. 1, p. 156-163, 2014

YUN, S. I.; RO, H. M. Natural $15 \mathrm{~N}$ abundance of plant and soil inorganic-N as evidence for overfertilization with compost. Soil Biology and Biochemistry, v. 41, n. 7, p. 1541-1547, 2009.

ZHANG, F. et al. Potassium nutrition of crops under varied regimes of nitrogen supply. Plant and Soil, Wageningen, v. 335, n. 1-2, p. 21-34, 2010 